\title{
Internet resources for journalism/communications
}

\author{
By John A. Olson and Patience L. Simmonds
}

\section{News and media information on the Net}

$\mathbf{N}$ ow more than ever, the right information at the right time is crucial to our very existence. The Internet has made it possible to access sources and information which were previously unavailable. Journalism and communication resources on the Internet provide people with a wide array of materials to make human interaction much more interesting.

It is now easier to do serious research in journalism and communications and also find interesting and entertaining things on the Internet. The resources compiled here try to cover the gambit, or at least hit the highlights of the subject. Many of the commonly used search engines were used: Yahoo, Lycos, Excite, Infoseek, and Webcrawler. These engines provided valuable and informative sites emphasizing communication, education, research, and other closely allied subjects.

Not all the sites and links found on the Net can be covered here, but the resources listed are meant to help the serious researcher, the "armchair" journalist, and people interested in communication studies.

\section{Best starting places/megasources}

Each of the megasource pages listed below also include sections that should be searched while reading and exploring sites under the other headings listed in this guide.

- AJR NewsLink. From the American Journalism Review. Here is a well-laid-out front page that's easy to look at, easy to use, and fun to explore. Check out the "resource" section; this is where you will find the most information on other Web-linked resources pertinent to journalism and communications. There are also links to newspapers, magazines, broadcasters, television/radio, and news services. This site is worldwide in scope. The Alta Vista search engine is used to search the contents of this site. An all encompassing site for journalism that shouldn't be missed. Access: http://www. newslink.org/menu.html.

- The WWW VIRTUAL LIBRARY: JOURNALISM. Edited by John S. Makulowich. Broken down into ten different sections, this site includes a search engine to find sources within this page that allows specific searching from any one of the ten sections. Nicely classified, bare bones, and efficient in design. No glitzy color here. Covers broadcasting, communications, media, and news. An excellent site for journalism, communications, and related fields. This is a must site and should be bookmarked. Access: http://www.cais.com/makulow/vlj.html.

- Communication Sites. Produced by December Communications, which specializes in publications, presentations, and consulting needs related to the Web. This is just one link in the vast array of information available on this page. This particular section called "Applications-Communications" lists topics by broad general user type from the individual, group, organizational, and societal uses of communication. Access: http://www.december.com/ $\mathrm{cmc} /$ info/applications-communication.html.

- Journalism and Mass Communication. From the University of Iowa comes a massive and extensive site of journalism and communication sources arranged by subject. This is not updated as frequently as other sites but it is just as good if not more extensive than 
some of the better commercial sites. Very complete and comprehensive as well as easy on the eyes and easy to understand. Access: http: //www2.arcade.uiowa.edu/gw/journalism/.

- Poynter Online. From the Poynter Institute for Media Studies. Probably the best organized of the corporate sites. Nice simple layout for finding any and all aspects of journalism. Why go anywhere else? Access: http:// www.reporter.org/poynter/je/je_jsites.htm.

\section{Discussion groups}

There are many discussion lists for the many areas constituting journalism and communications. This a selective list of available sites.

- CARR-L. Focuses on computer-assisted research and reporting. A great resource for working journalists. Subscribe: listserv@ ulkyvm.louisville.edu.

- JOURNET. Discussion for journalism education. Subscribe: listserv@qucdn.queensu.ca.

- SPJ-L. Listserv for the Society of Professional Journalists. Frequented mostly by working journalists, but subscription is open. Subscribe: listserv@psuvm.psu.edu.

- JEA-L. Official mailing list of the Journalism Education Association. Subscribe: listserv@spub.ksu.edu.

- NewsLib. For news librarians, researchers and journalists. Subscribe: listserv@ gibbs.oit.unc.edu.

- STUMEDIA. Forum for the discussion of all issues of student journalism. Subscribe: listserv@uabdpo.dpo.uab.edu.

- ACA-L. American Communication Association. Subscribe: listserv@uafsysb.uark.edu.

- CRTNET. Communications and Research and Theory Network. Subscribe: listserv@ psuvm.psu.edu.

- COMLIB-L. Communications Librarians Discussion List. Subscribe: listserv@lsv.uky.edu.

- LM_NET. School of Library Media \& Network Communication. Subscribe: listserv@ listserv.syr.edu.

- MEDIA. Investigative journalism. Subscribe: listserv@sokrates.mip.ki.se.

- BRDCST-L. List for professionals and academics covering all issues of broadcasting and cable. Subscribe: listserv@unlvm.unl edu

- FOI-L. For journalists, academics, and government officials interested in information issues. Subscribe: listserv@listserv.syr.edu.

- RADIO-L. Discussion group of digital audio broadcasters (1)AB). Subscribe: listserv@tc. umn edu.

\section{Newsgroups/usenets}

Newsgroups in the areas of journalism and communications abound on the Internet. This is a very selective list.

- Deja-news. A search engine for newsgroups on the Web. Access: http://www. dejanews.com/.

- alt.journalism. Journalism and journalism students. Access: news:alt.journalism.

- alt.journalism.criticism. Access: news:alt.journalism.criticism.

- alt.journalism.gay-press. News from a gay viewpoint. Access: news:alt.journalism.gaypress.

- alt.journalism.newspapers. Access: news:alt.journalism. newspapers.

- alt.journalism.students. Access: news:journalism.students.

- clari.biz.industry.media (moderated). Publishing, journalism, and media. Access: news:clari.biz.industry.media.

- alt.journalism.moderated (moder ated). Access: news:alt.journalism.

- alt.news-media. Access: news:alt.newsmedia.

- rec.radio.broadcasting (moderated). Discussion of global and domestic broadcast radio. Access: news:rec.radio.broadcasting.

\section{Electronic journals/magazines}

There are two sites listed here that contain a number of other mainstream publications in journalism and communications.

- AJR. American Journalism Review. An online site that lists titles and some full-text articles from its print journal. Access: http:// www.newslink.org/ajtoc.html.

- CJR. Columbia Journalism Review. This site lists the tables of contents from its journal for the past year and a half. Access: http:// www.cjr.org/.

- Editor \& Publisber. An interactive edition which has some different articles from its paper counterpart. Access: http://www.media info.com/

- Journalism Library. From Columbia University's Journalism Library. Many journals to choose from and this complements the University of Iowa's list of journals found in the next entry. Access: http://www.cc.columbia. edu/cu/libraries/indiv/jour/ejournals.html

- Journalism Magazines OnLine. The University of Iowa Libraries has compiled a list of sixteen journals from around the world with links. A wide choice of journals are listed cov- 
ering a wide spectrum of journalism and related topics. Access: http://www2 arcade. uiowa.edu/gw/journalism/jmagazines.html.

\section{Academic journalism and communication sites}

- Academic Communications Sites Around the World. Includes communications, journalism, and media sites around the world. The sites are sorted by region and then by country. North America is more comprehensive than some of the other regions listed. Access: http: //www.jou.ufl.edu/commres/jouwww.htm.

- WebOvision's Journalism and Media Links. Contains journalism and media links, journalism schools, and organizations in the U.S. and around the world. There is also a search engine on this page to search documents on the WebOvision site. Access: http://www. catalog.com/media/sd/journal.html.

- ACA (American Communication Association) List of Communication Departments. Includes a comprehensive list of academic communication departments arranged alphabetically. Access: http://www.uark edu/ depts/comminfo/www/departments.html.

- Internet Journalism Resources. A comprehensive and well-organized site with links to resources for international journalism. Journalism resources are grouped under regions and then under subject headings. Access: http: //www.moorhead.msus.edu/ gunarat/ijr/

- The World-Wide-Web Virtual Library: Communications and Telecommunications. A great site for searching communications and telecommunications information. Provides links to sites for national and international telecommunications, television, and radio broadcasters. Access: http://www analysys. co.uk/conmslib.htm.

\section{Organization/association sites}

Make sure to check out the organization and association sections in the best starting places/ megasource section. Here are just a few of the many professional organizations and associations that have sites on the net.

- National Press Club. This site has grouped its links for easy access to information dealing with national issues. Provides hotlinks to political coverage sites and resources for reporters. Nicely laid out and easy to read. $A C$ cess: http://npc.press.org/

- American Communication Association. A not-for-profit organization that promotes the principles of communication through teaching and research. Access: http://cavern. uark.edu/comminfo/www/about.aca.html

- American Society of Journalists and Authors. This site is aimed at independent nonfiction writers. This is the professional Web page of the ASJA. Access: http://www.asja.org/.

- The Society of Professional Journalists. This is the professional homepage for the SPJ. Here you will find information about the organization's listserv and Quill, its professional journal. This site is for the editorial professional and those involved in the editorial side of publishing. Nicely laid out and easy to use. Access: $\mathrm{ftp} / /$ ftp.netcom.com/pub/sp/spj/html/spj.html.

\section{Mass media sources: TV, radio, film}

- Broadcasters. Part of the Virtual Library from Oxford University, this is one long list grouped by subject including media, newsgroups, satellite information, broadcasters, and other sources. The broadcasting section is broken down by county but is not as complete as some other lists. Access: http://www.comlab. ox.ac.uk/archive/publishers/broadcast.html.

- UTV-The Ultimate TV Network. This site has lots of color and is well laid out. Links to news articles about TV-related items are a nice touch. The small front page loads quickly and is well indexed and updated daily. Access: http://www.utv.net/.

- Media Web. Brought to you by Temple and Rice Universities, this is a compilation of sites related to film, TV, and video along with links to other related media sites. Updates are infrequent on this page. This site is a long alphabetical list of links each with its own description. Access: http://www ruf.rice.edu/ media/MediaWeb/web.html.

- International Shortwave Broadcasters. An alphabetical, geographical listing of the available Web sites of international shortwave radio broadcasters and their homepages. Some of the sites are quite colorful, entertaining, and informative. A nice list. Access: http://acorn. educ.nottingham.ac.uk/SchEd/pages/radio/

- Radio Netherlands Hit List. A well-organized site with lots of resource links and international radio links grouped by continent, including related media pages. Access: http:/ woww.rnw.nl/en/pub/hitlist.html.

\section{News services}

- News Resource. This site has a nice clickable image map to take you directly to the 
geographic area you are looking for with information on radio, television, newspapers, and magazines. Also has the major news agencies' links for quick access. Nice and simple. Access: http://newo.com/news/.

- Total News. An interesting and logical layout for getting quick access to late-breaking headlines with the ability to see the details for that headline. Includes both a clickable image map and text links. Access: http://totalnews. $\mathrm{com} /$ main.html.

- N.E.W.S. For you list-oriented individuals this site is arranged by news subject, weather, sports, and entertainment news stories. Has a good list of the main big time sites and is updated frequently. Access: http://www.niu.edu/ newsplace/news.html\#e-pubs.

\section{Magazines, e-journals, newspapers}

- NEwSTAND. By Ecola Directories. Lists more than 2,600 sites of newspaper and magazine Web pages. Most of the sites are English in content and have unrestricted access and a search engine to find the publication name. Well laid out and easy to read and understand. $A C$ cess: http://www.ecola.com/news/.

- E-journal. Produced by e.doc. Provides access by subject area to different types of newspapers, journals, magazines, and other information. Also has a search engine that has direct links to publishing companies and the World Wide Web Virtual Library. Small front page with a concise index of links. Access: http: www.edoc.com/ejournal/.

- E-Zine List. Want to find an e-zine? Here's one place to find it. Broken down by subject, the site includes, at latest count, almost 1,500 e-zines in either electronic form or in paper. Also describes what e-zines are. Easy to use and comprehensive. Access: http:// www.meer.net/ johnl/e-zine-list/.

- ENEWS. Says it's the "Ultimate Magazine Site." This Web site that uses frames lists more than 200 magazine homepages and Web sites. Broken down into broad subject categories and then narrower terms under each heading. You can customize your searches. This is a commercial site so it does look glitzy and incluctes advertisements. Has a nice layout. Access: http: //www.enews.com/body.html.

- YAHOO Entertainment Magazines. In the typical Yahoo layout there are subject entries listed first, followed by a listing of the links for magazines and e-zines. Each link includes a brief annotation. Plus there's always the Ya- hoo search engine at the top of the page for searching within the subject. Can't go wrong at this site. Access: http://www.yahoo.com/ entertainment/magazines/

\section{- Newspapers Accessible on the Inter-}

net. This is a newspaper-only site from the University of Virginia and is broken down by country or continent and then an alphabetical search jump-to index. The list of titles is by geographic subject entry. This is a long list and takes a while to load but is still worth a look. Access: http://www.lib.virginia.edu/cataloging/ vnp/paplist.html.

- Hot Links to Newspapers. This is a listing of URLs and contacts for newspapers around the U.S. only. Nice clickable image map for easy jumping within the list. Lists a number of other relevant sites concerning newspapers and news in general. Access: http://www.naa.org/ hot/hot.html.

- Newspapers On-line. A nicely laid out simple page for newspapers, other newsprint sources, and tools both inside and outside the U.S. Easy to look at and easy to use. Access: http://www.newspapers.com/

\section{Tools, resources, and interesting sites}

- Magazine and Newsletter Editors' Resource List. A large site providing references and news associations for those in the editorial arena of the periodical industry. The page is nicely laid out and has an easy "click-to" index at the top. A large alphabetical list that's nicely arranged. Even has library sites listed. An all encompassing list. Access: http:/ www. fileshop. $\mathrm{com} / \mathrm{personal} / \mathrm{tgoff} /$ erlist.html.

- MPF Sites on the Internet Resources for Marshaling and Presentation of Facts. A resource guide that locates various tools to assist in the nuts and bolts process of gathering, formatting, and publishing information. Aimed at anyone who is involved in the information gathering and dissemination process. Describes each site listed. Very comprehensive in its scope. Access: http://www.cais.net/danw/ mpflist.html.

- Journalism and Media Criticism Page. From the College of Humanities and Social Science at Montclair State University. Emphasis is on journalism criticism. Here are sites that study and analyze alternative media, film, television, and the print media. There are annotations for each entry listed here. Listings for alternative media, media literacy, and journalism history with links to newspapers, listservs, and other 
mega-sites. Access: http://www.shss.montclair. edu/english/furr/media.html

- CRAYON. Create Your Own Newspaper. Selection is a breeze in a well-executed, stepby-step design. The site allows you to select the type of news links and from where. It also lists which sites, in order of preference, are picked by those who've created their own paper before you; more than 60,000 people have. Access: http://crayon.net/

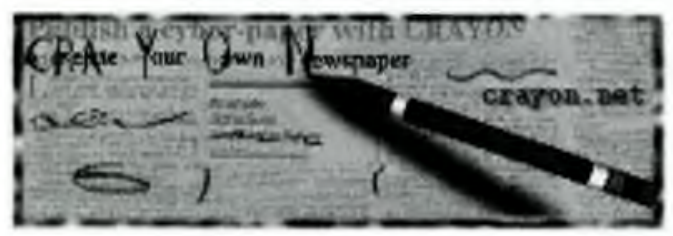

- FCC-The Federal Communications

Commission. Regulates interstate, international communications by radio, television, wire, satellite, and cable. Lists links to all of the FCC's business. Also listed is the Telecommunications Act of 1996. Access: http://www.fcc.gov/

- Communications Decency Act of 1996. A site all librarians should know about since there are now challenges in the courts from ALA and other groups. Information is broken down into broad sections within subsections. Access: http://www rahul.net/starowl/ cda-text.htm.

- Journalist's Toolbox. Produced by the National Scholastic Press Association and Associated Collegiate Press. This site is aimed at university, college, and high school newspapers and press people. Very useful sites for all aspects of mass media and publishing-related sites. Nicely laid out and alphabetical in orientation. Easy to look at and use. Access: http:// studentpress.journ.umn.edu/Toolbox.html.

- Media Watchdog. Offers links to sites that watch media sources and emphasizes watching and discussing the accuracy and bias in the mainstream media. The site is broken down into five subject groups: time sensitive information, media criticism organizations and resources, media criticism articles, censorship resources, and other resources. Access: http:// theory.lcs.mit.edu/ mernst/media/.

- The EraM program. Here is a site with an interest in issues relating to ethnicity, racism, and the media aimed at academics, students, and media professionals. Listed are some megasites, TV/radio sites, organizations, and academic sites. Access: http://www.brad.ac.uk/ research/eram/wwwsites.html.
(New age cont, from page 76)

and faculty go to libraries, and only one of them is to gain access to collections. If a library system wants to reassert its right to be considered the heart of the university, it needs to think about those reasons, and make sure its building plans take them into account. Here are some of the reasons I think there will always be a need for library buildings:

- students and faculty need the assistance of information professionals and will prefer to secure that assistance in person whenever possible;

- students need places where information resources are available so they can meet with classmates to work together on class projects;

- students need to get out of noisy dorm rooms and family homes so they can concentrate on their studies;

- libraries frequently will have better workstations, printers, and/or network connections than are available to students or faculty at home;

- students and faculty like the ambiance of libraries (and bookstores) and find it conducive to learning;

- students are social beings, and like being in the midst of other people.

An example of how these assumptions have informed the building of a new library can be seen at George Mason University's Johnson Center, which includes a library, bookstore, food services, theater, Media Authoring Center, and student and academic program offices. For a preview, go to our homepage at http:// ulcweb.gmu.edu. Ed. note: See C\&RL News, May 1996, for an overview of the center.

\section{Learn more about building libraries}

If you enjoyed this article, you may want to attend the preconference Hurt developed for ACRL called "Building the New Age Library," Friday, April 11, 1:00-4:30 p.m., in Nashville. It will cover new ways of thinking about library buildings and provide practical examples using the Johnson Center at GMU, including its food services, book store, computer labs, movie theater, and more. For registration information see the preliminary program in the January issue of CERL News or check the conference homepage at http: //www.ala.org/acrl.html. 


\section{New For Spring! Thermal}

Edited by

\section{Characterization}

Edith A. Turi

Polytechnic University, Brooklyn. New York

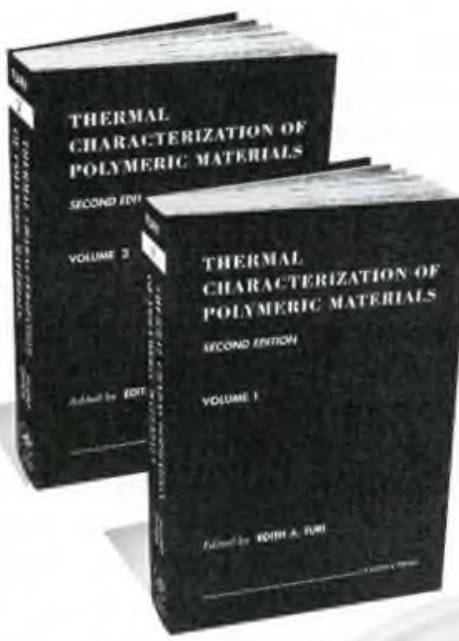

Praise for the Filst Edwion

"What this reviewer found most impressive about this text is the smooth fiow and coordination from chapter to chapter, no doubt a result of the excellent editing ablitities and knowledge of the editor.

- JOURNAL OF THE AMERICAN CHEMICAL SOGETY

"IIt is] a comprehensive, authoritative treatment of the subject. recommended for academic and industrial libraries as well as for the desk of individuals involved in thermal analysis, or in the research, production and application of polymeric materials."

-JOURNML OF POLYMEA SCIENCE

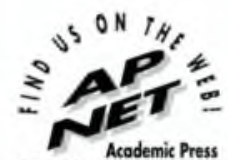

Acodemic Press
http://www,apnet.com/

\section{of Polymeric Materials}

\section{Second Edition}

The Second Edition of Thermal Characterization of Polymeric Materials.

: edited by Edith A. Turi, continues the tradition of the widely acclaimed original work, providing a comprehensive and fully current review of the literature and

techniques of thermal analysis of polymers. This two-volume set provides an in-depth overview of thermal analysis by focusing on instrumentation and a wide

array of applications in research, development, production, quality control and technical service. The chapters are well-coordinated, clearly written and are replete with practical examples. Each chapter is written by world-renowned authors and includes important but previously unpublished experimental data. Fully revised and updated, this text has grown from 960 to approximately 2500 pages, reflecting the explosive development of the field during the 16 years since the publication of the first edition. This comprehensive two-volume set is destined to become an invaluable reference source for chemists, engineers, physicists, and other professionals involved in research, development. production, applications, characterization, and evaluation of polymers.

\section{KEY FEATURES}

- Revised and updated throughout

- Highlights the characteristics of commercial instruments and applicability to particular needs

- Helps readers to eliminate costly trial-and-error experiments by judicious use of the examples described

- Provides extensive references to the primary literature

- Features thermal curves, diagrams, and other illustrations, allowing readers to evaluate their own data

CONTENTS: P.K. Gallagher, Thermoanalytical Instrumentation, Techniques and Methodology. B. Wunderlich. The Basis of Thermal Analysis. R.P. Chartoff. Thermoplastic Polymers. A. Hale and H.E. Bair, Polymer Blends and Block Copolymers. A.K. Sircar, Elastomers, R.B. Prime, Thermosets, M. Jaffe, J.D. Menczel, and W.E. Bessey, Fibers. J.D. Menczel, M. Jaffe, and W.E. Bessey,

Films. RJ. Morgan, Thermal Characterization of Composites. H.E. Bair. Thermal Analysis of Additives in Polymers.

Two-Volume Set

Prepublication price: $\$ 295.00^{*}$

Fetriary 1997, c 2540 pp. \$375.00/5BN: 0-12-7087a3-7

"Valid through April 30, 1997

Order from your local bookseller or directly from:

\section{Academic Press}

Order Fulfillment Dept. DM27098

24-28 Oval Road, London NW1 7DX, U.K.
6277 Sea Harbor Drive, Orlando, FL 32887
In the U.S and Canada

CALL TOLL FREE: 1-800-321-5068

FAX: 1-800-874-6418

E-MAIL: ap@acad.com

In Europe, CALL: 0181-300-3322

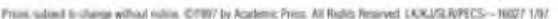

